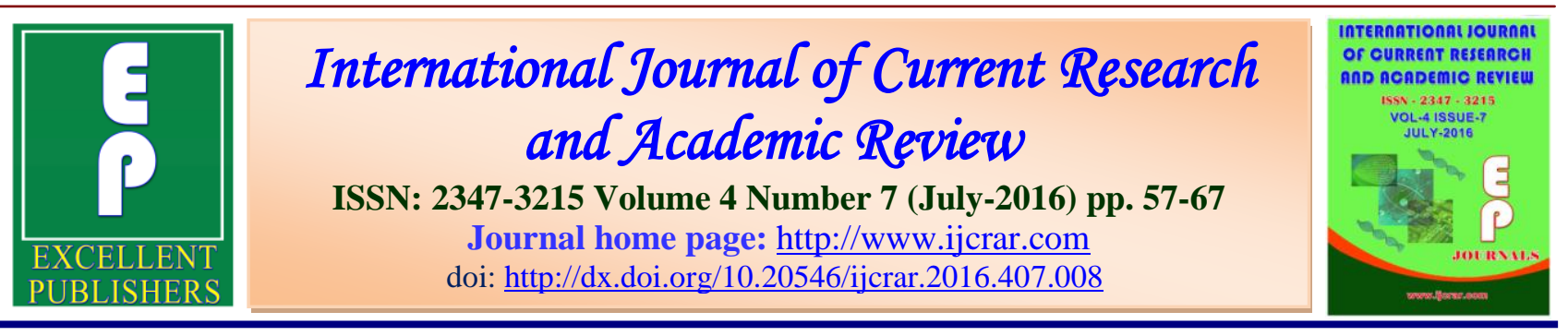

\title{
Biophytum sensitivum Chemical Constituents and Medicinal Properties: A Review
}

\author{
Mathew George, Lincy Joesph and Umesh Kumar* \\ Pushpagiri College of Pharmacy, Tiruvalla, Kerala-689107 \\ *Corresponding author
}

KEYWORDS

Biophytum

sensitivum, phytochemical, phytocontituents.

\section{A B S T R A C T}

World is rich in knowledge with a wide diversity of medicinal plants which provide people with traditional healing methods for diseases in general healthcare area. Biophytum sensitivum is a plant with various medicinal properties such as analgesic, anti-pyretic, anti-inflammatory, immunomodulatory, antitumor, antidiabetic, antioxidant, antibacterial, antihypertensive, chemoprotective, radioprotective, antifertility and antiasthmatic. This review study provides an extensive detail about the phytochemical, pharmacological and folkloric uses of Biophytum sensitivum. It has been used indigenously in the field of Ayurvaeda, Sidhha and Unani for many decades. Various parts of the plant has the presence of variety of phytoconstituents such as flavonoids, saponins, tannins, terpenes, steroids, amino acids, essential oil, polysaccharides and pectin.

\section{Introduction}

The genus Biophytum is a member of the family Oxalidaceae and distributed in tropical Asia, Africa, America and the Philippines. In India, nine species of Biophytum are prominently found and out of these, three species viz. Biophytum sensitivum DC. Syn. Oxalis sensitivum Linn., Biophytum reinwardtii Edgew and Biophytum umbraculum Welw. Syn. Biophytum petersianum Klotzsch are reported to have ethnomedicinal potential. Biophytum sensitivum (L.) DC (B. sensitivum), commonly known as 'Life plant', is a mesophytic under-shrub growing in slightly moist places. The plant is distributed up to an altitude of 1,800 $\mathrm{m}$ and is available during the rainy season in moist shady places (Warrier et al., 2014). The plant is traditionally used for centuries in the treatment of various health aliments. It is an important medicinal plant in the Indian traditional system of medicine like Ayurveda (The wealth of India, 1988). It is extensively used for its wide therapeutic potential such as analgesic, anti-pyretic, anti-inflammatory, immunomodulatory, antitumor, antidiabetic, antioxidant, antibacterial, antihypertensive, chemoprotective, radioprotective, antifertility and anti-asthmatic. 


\section{Description}

It is a small plant, rarely exceeds $2.5-20 \mathrm{~cm}$ in height and form an unbranched woody erect stem. All leaves grow on the top of the stem. Leaves are abruptly pinnate, sensitive, $3.8-12.7 \mathrm{~cm}$ long and are made of 8-17 pairs of leaflets. Leaflets are opposite, $1 \mathrm{~cm}$ long, terminal pairs the largest and pairs becoming smaller downwards. Flowers are dimorphic, $8 \mathrm{~mm}$ across, yellow and crowded at apices of the peducles. The sepals are lanceolate, 7 $\mathrm{mm}$ long with parallel nerves. Corolla is much exceeding the sepals. Lobes are rounded and spreading. Style is nearly glabrous. Fruits are ellipsoid capsule. Seeds are prominently ridges and transversely striated. The plant has been observed flowering and fruiting in the month of September to December (CSIR, 2004; Pullaiah, 2006).

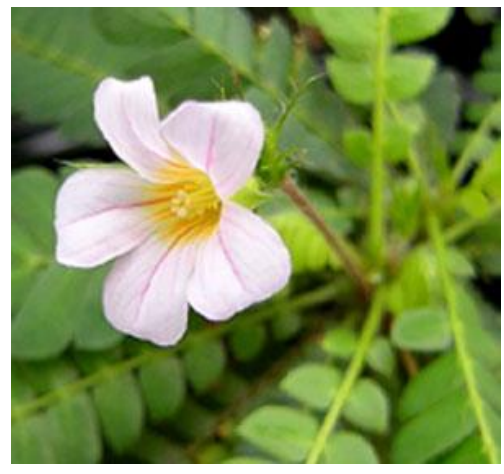

\section{Flower of Biophytum sensitivum}

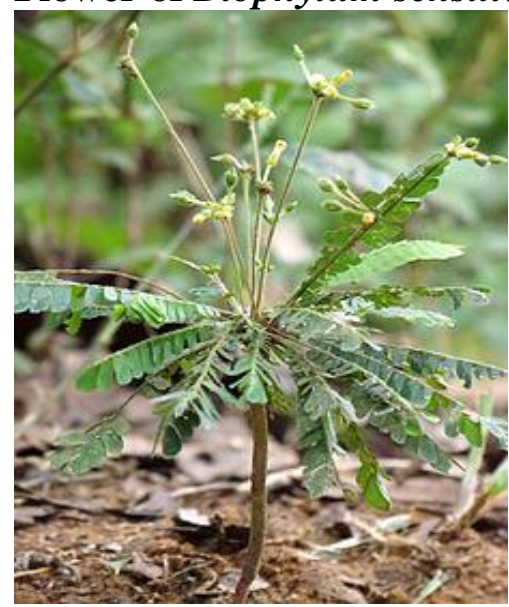

Whole plant of Biophytum sensitivum

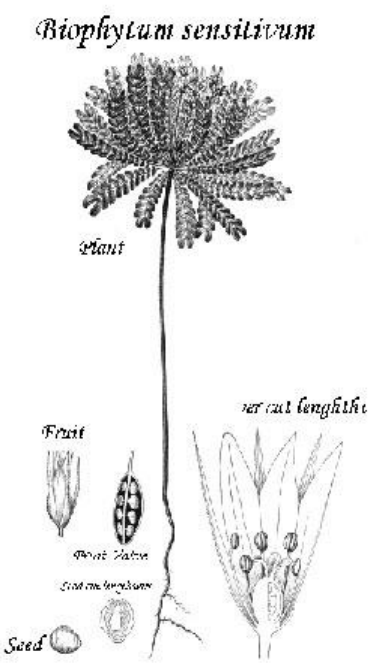

\section{Different parts of Biophytum sensitivum}

Taxonomical classification (Pullaiah, 2006)

Kingdom: Plantae

Phylum: Tracheophyta

Class: $\quad$ Magnoliposida

Order: Oxalidales

Family: Oxalidaceae

Genus: Biophytum

Species: sensitivum

Botanical name:Biophytum sensitivum (L.)

DC

Vernacular names (Editorial Committee of the Flora of Taiwan, 1993)

Common name: Life plant, little tree plant, sensitive plant

French: alleluia

Bengali:Jhalai

Hindi:Lajalu, Lajjaalu, Lakshmana, Zarer

Indo-China:Chua me

Kannada:Haramuni, Jalapushpa

Malayalam:Mukkutti

Marathi:Jharera, Lajwanti, Lahanmulaka

Sanskrit:Jhullipuspa, Lajjaluka, Panktipatra, Pitapushpa, Vipareetalajjaalu

Tamil:Nilaccurunki, Tintaanaalee

Telugu:Attapatti, Chumi, Jala pupa 
Physiochemical analysis (Kumaratunga, 2003)

\section{Extractable Matter}

Crushed, air dried plant material (about $4 \mathrm{~g}$ ) was weighed to a glass-stoppered conical flask. Solvent $(100 \mathrm{~mL})$ was added, weighed, shaken well and allowed to stand for $\mathrm{lh}$. It was then boiled for $1 \mathrm{~h}$ and cooled. The weight was readjusted with specified solvent and filtered Filtrate $(25 \mathrm{~mL})$ was taken, solvent was evaporated and oven dried at $105{ }^{\circ} \mathrm{C}$ for $6 \mathrm{~h}$, cooled in a desiccator and weighed.

\section{Total Ash}

Crushed, air dried plant material (about $4 \mathrm{~g}$ ) was weighed to a previously ignited crucible. The material was ignited by gradually increasing the temperature to $550^{\circ} \mathrm{C}$ until it was free from carbon. The crucible was cooled and weighed

\section{Acid Insoluble Ash}

Hydrochloric acid $(25 \mathrm{~mL}$, cone. $-70 \mathrm{~g} / \mathrm{L})$ was added to the crucible containing total ash, covered with a watch glass and boiled gently for $5 \mathrm{~min}$. The insoluble matter was collected on an ashless filter paper and washed with hot water until the filtrate was neutral. The filterp aper containing the insoluble matter was transferred to the original crucible and ignited to a constant weight.

\section{Water Soluble Ash}

Water $(25 \mathrm{~mL})$ was added to the crucible containing total ash, covered with a watch glass and boiled gently for $5 \mathrm{~min}$. The insoluble matter was collected on an ashless filter paper and washed with hot water. The filter paper containing the insoluble matter was transferred to the original crucible and ignited for $15 \mathrm{~min}$. at a temperature not exceeding $450{ }^{\circ} \mathrm{C}$. Water soluble ash is the calculated difference in weight between the total ash and the residue remaining after treatment of the total ash with water. Moisture content of the samples was estimated and all the calculations were done on dry weight basis.

\section{Phytochemistry (Abinash et al., 2012)}

Phytochemical studies of $B$. sensitivum showed that it contains a number of phenolic and polyphenolic compounds, saponin, essential oil, polysaccharides and pectin. The main bioactive constituents found are bioflavonoid, amentoflavone with minute amount of cupressoflavone.

Other than amentoflavone, the flavonols present were luteolin 7-methyl ether, isoorientin, 3'-methoxyluteolin 7-Oglucoside, as well as two acids, 4caffeoylquinic acid and 5-caffeoylquinic acid, that were isolated from aerial parts of $B$. sensitivum. Further isolation and quantification of C-glycosyl flavones and proanthocynidin from the plant showed the presence of isoorientin, orientin, isovitexin, isoorientin 7-O-glucoside, isoorientin 2"-Orhamnoside in methanolic extract of the leaves. From the roots, (-)-epicatechin and

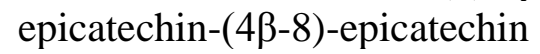

(proanthocynidin B2) were isolated and the highest amount of C-glycosyl flavones was found in leaves. The essential oil of airdried $B$. sensitivum was investigated by gas chromatography-spectroscopy (GC-FID and GC-MS) and was found to contain mainly 1,4-dimethoxy benzene (24.9\%), 1,2dimethoxy benzene (10.6\%) and 2-methoxy4-methyl phenol (3.5\%), the monoterpenes (Z)-linalool oxide $(8.1 \%)$, (E)-linalool oxide $(5.2 \%)$, linalyl acetate $(3.4 \%), 1-$ octen-3-ol (9.5\%), isophorone (3.1\%), and 
69 minor compounds. The water extract of aerial parts contains a bioactive polysaccharide, BP100 III, major part of which is composed of galacturonic acid and rhamnose, with branches being present on both the rhamnose and galacturonic acid residues.

\section{Medicinal Uses}

The study revealed the insulinotropic effect of Biophytum sensitivum. The antiinflammatory activity of aqueous and methanol extracts of aerial parts and roots were studied in the carrageenin-induced rat paw oedema model. All the extracts except the methanol extracts of aerial parts exhibited anti-inflammatory activity. Apart from this, mostly in ayurveda, this is a tonic, stimulant and in the treatment of stomach ache, diabetes and asthma. It is also used in insomnia, convulsions, cramps, chestcomplaints, inflammations, tumors, chronic skin diseases.

Uses as folklore medicine (Council of Scientific and Industrial Research, 1988; CSIR, 2004; Kirtikar et al., 2005)

The whole plant is dried, powdered and given internally to cattle to stop excessive salivation. In the Philippines, the powdered seeds are used as vulnerary and along with butter they are applied to abscesses to promote suppuration. The crushed whole plant is used in chronic skin troubles and is also eaten to induce sterility in man. A decoction of the leaves is given in asthma and phthisis. The plant is also used in chest complaints, insomnia and convulsious cramps and inflammatory tumors. The plant decoction is used in amenorrhea and dysmenorrhea and its powder for the gonorrheal infection and lithiasis.

\section{Activity studies}

Analgesic activity and Anti-pyretic activity (Chatterjee et al., 2008)
The analgesic activity of methanolic extract of Biophytum sensitivum showed analgesic effect by Tail flick method at the doses of 100 and $200 \mathrm{mg} / \mathrm{kg}$ in mice. The analgesic activity in respective doses was found to be $54.93 \%$ and $67.91 \%$ against acetic acid induced writhing in mice.

It was concluded that methanolic extract showed significant increase in activity at higher dose. The anti-pyretic activity of methanolic extract of Biophytum sensitivum was tested against yeast induced pyrexia in rats. The results showed that the rats treated with plant extract at the dose of 100 and 200 $\mathrm{mg} / \mathrm{kg}$ showed significant decrease in body temperature and also this decrease is dose dependent.

\section{Anti-inflammatory activity}

The methanolic extract of whole plant of $B$. sensitivum was reported to have significant anti-inflammatory activity at the dose of 100 and $200 \mathrm{mg} / \mathrm{kg}$ in the carrageenin-induced, histamine-induced and dextran-induced paw oedema model in the rats (Jachak et al., 1999). Anti-inflammatory activity of aqueous extracts of aerial parts and roots, methanol extract of aerial parts and ultrafiltration fractions of a methanol extract of roots of $B$. sensitivum were also evaluated in the carrageenin-induced rat paw edema. All the fractions except the methanol extract of aerial parts inhibited the formation of carrageenin-induced paw edema (Sekhar et al., 2012).

Amentoflavone and procyanidines isolated from the $B$. sensitivum has been reported to possess in vivo anti-inflammatory activity and to inhibit COX when tested in vitro. Amentoflavone has been reported to downregulates COX-2 expression with concomitant inhibition of NF- $\kappa \mathrm{B} / \mathrm{DNA}$ binding activity with inhibition of 
degradation of $\mathrm{I} \kappa \mathrm{B} \alpha$ and $\mathrm{NF}-\kappa \mathrm{B}$ translocation into the nucleus in $\mathrm{TNF} \alpha$ activated A549 cells (Guruvayoorappan et al., 2007).

\section{Immunomodulatory activity}

The methanolic extract of $B$. sensitivum increased the total WBC count and number of bone marrow cells. It is concluded that $B$. sensitivum has stimulatory effect on haematopoetic system, differentiation of stem cells and humoral arm of immune system. It is also found that the methanolic extract of $B$. sensitivum stimulates the immune cell system in Ehrlich ascites tumor bearing $\mathrm{BALB} / \mathrm{c}$ mice, leading to potentiation of immune cell proliferation and NK cell mediated tumor lysis (Inngjerdingen et al., 2008). The pectic polysaccharide (BP1002) obtained from a hot water extract of the aerial parts of $B$. sensitivum is reported to have ability to activate macrophages and dendrite cells (Gronhaug et al., 2011). The pectin polysaccharide (BPII) from the aerial parts of B. sensitivum and its fragments (BPII.1 and BPII.2) expressed immunomodulating activity against Peyer's patch immune competent cells and macrophages (Guruvayoorappan et al., 2008).

\section{Antitumor activity (Guruvayoorappan et} al., 2007; Inngjerdingen et al., 2008; Gronhaug et al., 2007)

The methanolic extract of $B$. sensitivum found to inhibit the growth of solid tumor induced by Dalton's lymphoma ascites (DLA) cells and ascites tumor induced by Ehrlich ascites carcinoma (EAC) cells. The extract was $100 \%$ toxic at a concentration of $0.5 \mathrm{mg} / \mathrm{ml}$ to both DLA and EAC cells. It was also found to be cytotoxic towards L929 cells in culture at a concentration of 0.1 $\mathrm{mg} / \mathrm{ml}$.
Methanolic extract of B. sensitivum have reported to produce apoptotic effect by regulating bcl-2, Caspase- 3 and p53 genes in B16F-10 cells and regulates nitric oxide and proinflammatory cytokine production in B16F-10 cells, TAMs and peritoneal macrophages. Amentoflavone isolated from the $B$. sensitivum found to augments lymphocyte proliferation, natural killer cell and antibody dependant cellular cytotoxicity through enhanced production of IL-2 and IFN-gamma and restrained serum sialic acid and gamma glutamyl transpeptidase production in Ehrlich ascites carcinoma cells bearing mice.

The aqueous extract of $B$. sensitivum leaves also found to inhibit the tumor volume, viable cell count and enhancement of survival time of DLA bearing mice. It is concluded that aqueous extract of $B$. sensitivum leaves has significant anti-tumor activity.

\section{Antiangiogenic}

(Guruvayoorappan et al., 2007)

activity

Amentoflavone isolated from B. sensitivum reported to inhibit tumor directed angiogenesis by disrupting the integrity of endothelial cells and by altering the endogenous factors such as IL-1 $\beta$, IL-6, TNF- $\alpha$, GM-CSF and VEGF that are required for the process of neovascularization. This antiangiogenic activity of amentoflavone is responsible for inhibition of tumor growth and metastasis.

\section{Antimetastatic activity}

Amentoflavone isolated from $B$. sensitivum reduced experimental tumor metastasis at the dose of $50 \mathrm{mg} / \mathrm{kg}$ for 10 consecutive days in $\mathrm{C} 57 \mathrm{BL} / 6$ mice injected with B16F10 melanoma cells (Guruvayoorappan et al., 2008). 
Int.J.Curr.Res.Aca.Rev.2016; 4(7): 57-67

$\begin{array}{llrll}\text { Amentoflavone } & \text { found } & \text { to } & \text { produce } & \text { Anti-bacterial activity (Natarajan et al., } \\ \text { antimetastatic } & \text { effect } & \text { by } & \text { altering } & \text { 2010) }\end{array}$
proinflammatory cytokine production and inhibiting the activation and nuclear translocation of p6, p50, c-Rel subunits of nuclear factor-kappaB, and other transcription factors such as c-fos, activated transcription factor-2, and cyclic adenosine monophosphate response element binding protein in B16F-10 melanoma cells (Guruvayoorappan et al., 2008).

Hypoglycaemic activity (Puri et al., 1998; Puri et al., 2001; Puri et al., 2008; Ananda et al., 2012)

The aqueous solution of $B$. sensitivum leaf extract was administered to rabbits at the dose of $200 \mathrm{mg} / \mathrm{kg}$ to study its effect on alloxan-induced diabetes. There was significant improvement in the glycaemic state in the subdiabetic and mild diabetic rabbits only. The results indicated that the $B$. sensitivum has hypoglycaemic effect mediated through pancreatic beta-cell stimulating action. The mild hypoglycemic activity of crude extract of $B$. sensitivum was also demonstrated in the obese glucoseintolerant rabbits at the dose of $200 \mathrm{mg} / \mathrm{kg}$.

Effect of oral administration of aqueous solution of $B$. sensitivum leaf extract at the dose of $200 \mathrm{mg} / \mathrm{kg}$ for 28 days was studied in normal and streptozotocin-nicotinamideinduced diabetic rats. The $B$. sensitivum leaf extract treatment significantly reduced the blood glucose and glycosylated haemoglobin levels and significantly increased the total haemoglobin, plasma insulin and liver glycogen levels in diabetic rats. It also increased the hexokinase activity and decreased glucose-6-phosphatase, fructose-1,6-bisphosphatase activities in diabetic rats. The results indicate that aqueous solution of $B$. sensitivum leaf extract possesses significant antidiabetic activity.

The methanol, chloroform, acetone and petroleum ether extracts of leaves of $B$. sensitivum showed antibacterial activity against B. subtillis, S. aureus, S. pneumonia, $K$. pneumonia, S. typhi, $P$. vulgaris and $E$. coli by agar well diffusion method in the range of $7-25 \mathrm{~mm}$. The acetone extracts showed remarkable anti-bacterial activity against $B$. subtillis. The extracts from the leaves exhibited considerable and variable inhibitory effects against most of the tested microorganism.

\section{Antioxidant activity (Guruvayoorappan et al., 2006)}

B. sensitivum extract was found to scavenge superoxide radicals, hydroxyl radicals and inhibited in vitro lipid peroxidation at concentrations of 50, 95 and $20 \mu \mathrm{g} / \mathrm{ml}$ (IC50) respectively. The extract also scavenged nitric oxide (IC50 $=100 \mu \mathrm{g} / \mathrm{ml})$. The extract found to induce the dosedependent scavenging of nitric oxide in culture.

Intraperitoneal administration of $B$. sensitivum extract inhibited superoxide generation in macrophages in vivo in mice. The extract also produced significant increase in catalase activity, glutathione, glutathione-S-transferase and glutathione reductase. The levels of glutathione peroxidase decreased after administration of $B$. sensitivum extract. These results indicate that $B$. sensitivum extract has significant antioxidant activity both in vitro and in vivo.

Antihypertensive activity (Titrikou et al., 2007)

The whole plant extract of B. sensitivum is reported to possess antihypertensive 
potential on guinea pig and rat model. The extract non-competitively antagonized calcium chloride and high- $\mathrm{K}^{+}$-induced contraction of isolated rat aorta in a concentration-dependant manner.

The extract also found to inhibit noradrenaline-induced contractions of aorta. These results strongly indicate that antihypertensive effect of $B$. sensitivum results from inhibition of calcium influx via both voltage and receptor operated calcium channels.

\section{Antifertility activity}

Ethanol, ethyl acetate, chloroform and nbutanol extracts of whole plant of $B$. sensitivum were studied for the antifertility potential at the dose of $400 \mathrm{mg} / \mathrm{kg}$ in female Wistar albino rats. All the extracts inhibited pregnancy with a significant reduction in number of implants as compared to control animals. The ethanolic extract exhibited maximum $(100 \%)$ antifertility activity. The activity was reversible on withdrawal of the treatment of the extract.

\section{Chemoprotective activity}

Intraperitoneal administration of alcoholic extract of Biophytum sensitivum increased the total WBC count, bone marrow cellularity, alpha-esterase positive cells and weight of lymphoid organs in mice with cyclophosphamide induced toxicity. The extract treatment found to restore GSH in liver and intestinal mucosa, serum and liver ALP, GPT and lipid peroxidation.

The B. sensitivum extract reduced the level of the pro-inflammaory cytokine, TNF- $\alpha$ and increased the levels of cytokines IFN- $\gamma$, IL-2 and GM-CSF in cyclophosphamide treated mice. It was concluded that Biophytum sensitivum has significant

$\begin{array}{lrr}\text { protective } & \text { activity } & \text { against } \\ \text { cyclophosphamide } & \text { induced } & \text { toxicity } \\ \text { (Guruvayoorappan } \text { et } \text { al., 2007). } & \end{array}$

\section{Radioprotective activity}

Methanolic extract of $B$. sensitivum was found to enhance immunity as well as stimulate production of IL- $1 \beta$, IFN- $\gamma$ and GM-CSF at the dose of $50 \mathrm{mg} / \mathrm{kg}$ in mice exposed to whole body gamma irradiation. It is concluded that $B$. sensitivum extract provides protection against radiationinduced hemopoietic damage (Guruvayoorappan et al., 2008).

\section{Larvicidal activity}

Acetone extract of leaves of $B$. sensitivum was found to be effective larvicidal, pupicidal and also interfered with the normal development and emergence of adult mosquitoes at the concentration of 10, 15 and $25 \mathrm{mg} / \mathrm{L}$ on Aedes aegypti mosquito in a dose dependant manner. It is concluded that $B$. sensitivum is having an excellent potential as Larvicidal agent against $A$. aegypti strain (Shivakumar et al., 2012).

\section{Complement fixing activity}

The aqueous extract of aerial part has the polysaccharide fraction, BP100 III, and has a monosaccharide composition typical for pectic substances, that exhibits potent dosedependent complement fixating activity. The fractions of BP 100 III were prepared by the endo- $\alpha$-D- $(1 \rightarrow 4)$-polygalacturonase

degradation. The highest molecular weight fraction is BP 100 III. 1 which has more potent activity in the complement test system than the native polymer which consists of galacturonic acid and rhamnose sugar having additional arabinogalactan type II in polymer (Inngjerdingen et al., 2006). 


\section{Anti-fungal activity}

The acetone extract of leaves of $B$. sensitivum had significant antifungal activity. The leaf extract of $B$. sensitivum inhibited the growth of fungal pathogens $A$. fumigatus, A. niger, $C$. neoformans and Norcardia sp. in disc method (Vijayan et al., 2010).

\section{Hypocholesterolemic effect}

The oral administration of the water extract of leaves of B. sensitivum to hypercholesterolemic rabbits at the dose of $200 \mathrm{mg} / \mathrm{kg}$ restored the lipid profile near to normal level. It is concluded that $B$. sensitivum has significant hypocholesterolemic effect (Puri et al., 2003).

\section{Safety and toxicity profile}

Acute toxicity of $B$. sensitivum extracts were studied in rodents. The methanolic extract of the $B$. sensitivum whole plant is well tolerated up to an oral dose of $4000 \mathrm{mg} / \mathrm{kg}$ of body weight as no mortality was observed within a period of $24 \mathrm{~h}$. The aqueous extract of leaves of the plant is studied and found non-toxic at the dose levels of 100, 200 and $300 \mathrm{mg} / \mathrm{kg}$ body weight by oral route in mice. The median lethal dose $\left(\mathrm{LD}_{50}\right)$ of the hexane, chloroform, ethyl acetate, n-butanol and ethanol extracts of the plant were found to be greater than $1 \mathrm{mg} / \mathrm{kg}$ when administered by intraperitoneal route to rats.

\section{Conclusion}

Biophytum sensitivum used for its wide therapeutic potential such as analgesic, antipyretic, anti-inflammatory, immunomodulatory, antitumor, antidiabetic, antioxidant, antibacterial, antihypertensive, chemoprotective, radioprotective, antifertility and anti-asthmatic. It possess potential to treat different ailments and still needs to be explored for various pharmacological activity. The future aspects of the plant can be anti asthmatic as it contains many of the phytochemicals and work has not been performed yet.

\section{References}

Abinash, C., Bharati and Alakh, N., Sahu. 2012. Ethnobotany, phytochemistry and pharmacology of Biophytum sensitivum DC. Pharmacogn Rev., 6(11): 68-73. doi: 10.4103/09737847.95893

Ananda, P.K., Kumarappan, C.T., Sunil, C., Kalaichelvan, V.K. 2012. Effect of Biophytum sensitivum on streptozotocin and nicotinamideinduced diabetic rats. Asian Pac. J. Trop. Biomed., 2(1): 31-5.

Bhaskar, V.H., Rajalaskshmi, V. 2010. Antitumor activity of aqueous extract of Biophytum sensitivum Linn. Ann. Biol. Res., 1(3): 76-80.

Chatterjee, T.K., Mishra, M., Pramanik, K.C., Bandyopadhyay, D. 2008. valuation of anti-inflammatory, antipyretic and analgesic properties of Biophytum Sensitivum. Indian Drugs, 45(2): 123-31.

Gronhaug, T.E., Kiyohara, H., Sveaass, A., Diallo, D., Yamada, H., Paulsen, B.S. Beta-D-( $1 \rightarrow 4)$-galactan-containing side chains in RG-I regions of pectic polysaccharides from Biophytum petersianum Klotzsch. contribute to expression of immunomodulating activity against intestinal Peyer's patch cells and macrophages. Phytochem., 72(17): 2139-47.

Guruvayoorappan, C., Afira, A.H., Kuttan, G. 2006. Antioxidant potential of Biophytum sensitivum extract in vitro 
and in vivo. J. Basic Clin. Physiol. Pharmacol., 17(4): 255-67.

Guruvayoorappan, C., Kuttan, G. 2007. Amentoflavone, a biflavonoid from Biophytum sensitivum augments lymphocyte proliferation, natural killer cell and antibody dependant cellular cytotoxicity through enhanced production of IL-2 and IFN-gamma and restrains serum sialic acid and gamma glutamyl transpeptidase production in tumor-bearing animals. J. Exp. Ther. Oncol., 6(4): 285-95.

Guruvayoorappan, C., Kuttan, G. 2007. Anti-angiogenic effect of Biophytum sensitivum is exerted through its cytokine modulation activity and inhibitory activity against VEGF mRNA expression, endothelial cell migration and capillary tube formation. J. Exp. Ther. Oncol., 6(3): 241-50.

Guruvayoorappan, C., Kuttan, G. 2007. Appoptotic effect of Biophytum sensitivum on B16F-10 cells and its regulatory effects on nitric aoxide and cytokine production on tumorassociated macrophages. Integr. Cancer Ther., 6(4): 373-80.

Guruvayoorappan, C., Kuttan, G. 2007. Effect of Biophytum sensitivum cellmediated immune response in mice. Immunopharmacol. Immunotoxicol., 29(3-4): 337-50.

Guruvayoorappan, C., Kuttan, G. 2007. Evaluation of the chemoprotective effect of Biophytum sensitivum (L.) DC extract against cyclophosphamide induced toxicity in Swiss albino mice. Drug Metabol. Drug Interact., 22(23): 131-50.

Guruvayoorappan, C., Kuttan, G. 2007. Immunomodulatory and antitumor activity of Biophytum sensitivum extract. Asian Pac. J. Cancer Prev., 8(1): 27-32.
Guruvayoorappan, C., Kuttan, G. 2008. Amentoflavone inhibits experimental tumor metastasis through a regulatory mechanism involving MMP-2, MMP9, prolyl hydroxylase, lysyl oxidase, VEGF, ERK-1, ERK-2， STAT-1, NM23 and cytokines in lung tissues of C57BL/6 mice. Immunopharmacol. Immunotoxicol., 30(4): 711-27.

Guruvayoorappan, C., Kuttan, G. 2008. Amentoflavone stimulates apoptosis in B16F-10 melanoma cells by regulating bcl-2, p53 as well as caspase- 3 genes and regulates the nitric oxide as well as proinflammatory cytokine production in B16F-10 melanoma cells, tumor associated macrophages and peritoneal macrophages. J. Exp. Ther. Oncol., 7(3): 207-18.

Guruvayoorappan, C., Kuttan, G. 2008. Anti-metastatic effect of Biophytum sensitivum is exerted through its cytokine and immunomodulatory activity and its regulatory effect on the activation and nuclear translocation of transcription factors in B16F-10 melanoma cells. J. Exp. Ther. Oncol., 7(1): 49-63.

Guruvayoorappan, C., Kuttan, G. 2008. Inhibition of tumor specific angiogenesis by Amentoflavone. Biochem., (Mosc) 73(2): 209-18.

Guruvayoorappan, C., Kuttan, G. 2008. Protective effect of Biophytum sensitivum (L.) DC on radiationinduced damage in mice. Immunopharmacol. Immunotoxicol., 30(4): 815-35.

Inngjerdingen, K.T., Coulibaly, A., Diallo, D., Michaelsen, T.E., Paulsen, B.S. 2006. A complement fixing polysaccharide from Biophytum petersianum Klotzsch, a medicinal plant from Mali, West Africa. Biomacromol., 7(1): 48-53. 
Inngjerdingen, M., Inngjerdingen, K.T., Patel, T.R., Allen, S., Chen, X., Rolstad, B., et al. 2008. Pectic polysaccharides from Biophytum petersianum Klotzsch, and their activation of macrophages and dendritic cells. Glycobiol., 8(12): 1074-84.

Jachak, S.M., Bucar, F,. Kartnig, T. 1999. Anti-inflammatory activity of extracts Biophytum sensitivum in carrageen ininduced rat paw oedema. Phytother. Res., 13(1): 73-4.

Johnson, D.B., Dinesh Kumar, C., Arunkanth, K.R., Giles, D., Gopal, M., Hubert, V.G. 2003. Antifertility activity of Biophytum sensitivum. Indian Drugs, 40(9): 523-5.

Kirtikar, K.R., Basu, B.D. 2005. Indian Medicinal Plants. Vol. I. Dehradun: International Book Distributor.

Kumaratunga, K.G.A. 2003. Gas chromatographic and Antimicrobial studies on Alpinia calcarata and Piper betle from Sri Lanka. M.Phil Thesis, University of Kelaniya, Sri Lanka.

Natarajan, D., Shivakumar, M.S., Srinivasan, R. 2010. Antibacterial activity of leaf extracts of Biophytum sensitivum (L.) DC. J. Pharm. Sci. Res., 2(11): 717-20.

Pullaiah, T. 2006. Encyclopedia of world medicinal plants. New Delhi: Regency Publication. Editorial Committee of the Flora of Taiwan; Flora of Taiwan, $2^{\text {nd }}$ ed. 1993.

Pullaiah, T. 2006. Encyclopedia of world medicinal plants. New Delhi: Regency Publication.

Puri, D. 2001. The insulinotropic activity of a Nepalese medicinal plant. Biophytum sensitivum: preliminary experimental study. $J$. Ethnopharmacol., 78(1): 89-93.
Puri, D. 2003. Hypocholesterolemic effect of Biophytum sensitivum leaf water extract. Pharm. Biol., 41(4): 253-8.

Puri, D. 2006. Screening mildly hypoglycaemic compounds: Obese British angora rabbits with borderline glucose intolerance as animal model. Indian J. Pharm. Sci., 68(5): 579-83.

Puri, D., Baral, N. 1998. Hypoglycemic effect of Biophytum sensitivum in the alloxan diabetic rabbits. Indian $J$. Physiol. Pharmacol., 42(3): 401-6.

Sekhar, S., Karmakar, R., Ramachandra, K.K., Siddapura, R.N., Harischandra, S.P. 2012. Potential anti-inflammatory bioactives from medicinal plants of Western Ghats, India. Pharmacogn. Commun., 2(2): 2-12.

Shivakumar, M.S., Srinivasan, R., Natarajan, D. 2012. Bioefficacy of Biophytum sensitivum (L.) leaf extracts against dengue mosquito vector Aedes aegypti (L.). Res. J. Pharm. Biol. Chem. Sci., 3(3): 885-92.

The wealth of India, 1988. A dictionary of Indian raw materials and industrial products (Raw materials) Revised Edition. New Delhi: Council of Scientific and Industrial Research.

The wealth of India: a dictionary of Indian raw materials and industrial products (Raw materials) first supplement series. Vol. I. New Delhi: National Institute of Science Communication and Information Resources, CSIR, 2004.

The wealth of India: a dictionary of Indian raw materials and industrial products (Raw materials) Revised Edition. New Delhi: Council of Scientific and Industrial Research.

The wealth of India: a dictionary of Indian raw materials and industrial products (Raw materials) first supplement series. Vol. I. New Delhi: National Institute of Science Communication 
and Information Resources, CSIR, 2004.

Titrikou, S., Eklu-Gadegbeku, K., Mouzou, A., Aklikokou, K., Gbeassor, M. 2007. Calcium antagonistic activity of Biophytum Petersianum on vascular smooth muscles of Wistar rat. Iran J. Pharmacol. Ther., 6(2): 185-9.

Vijayan, M.N., Barreto, 1., Dessai, S., Dhuri, S., D’Silva, R., Rodrigues, A. 2010.
Antimicrobial activity of ten common herbs, commonly known as 'Dashapushpam' from kerala, India. Afr. J. Microbiol. Res., 4(22): $2357-$ 62.

Warrier, P.K., Nambiar, V.P.K., Ramankutty, C. 1994. Indian Medicinal Plants-A Compendium of 500 Species, Vol. I. India: Orient Longman Publishers; 1994.

\section{How to cite this article:}

Mathew George, Lincy Joesph and Umesh Kumar. 2016. Biophytum sensitivum Chemical Constituents and Medicinal Properties: A Review. Int.J.Curr.Res.Aca.Rev.4(7): 57-67. doi: http://dx.doi.org/10.20546/ijcrar.2016.407.008 